\title{
MODEL BRAIN BASED LEARNING (BBL) UNTUK MENINGKATKAN HASIL BELAJAR SISWA SEKOLAH DASAR PADA POKOK BAHASAN SISTEM INDRA
}

\author{
Liah Badriah \\ Universitas Siliwangi \\ Jalan Siliwangi No.24, Kahuripan, Tawang, Kahuripan, Tawang, Tasikmalaya, Jawa Barat \\ Email: liahbadirah@unsil.com \\ Dani Ramdani \\ Universitas Siliwangi \\ Jalan Siliwangi No.24, Kahuripan, Tawang, Kahuripan, Tawang, Tasikmalaya, Jawa Barat \\ Email: daniramdani@unsil.com
}

\begin{abstract}
Abstrak
Penerapan Brain Based Learning (BBL) dalam penelitian ini digunakan untuk mengetahui peningkatan hasil belajar siswa Sekolah Dasar pada pokok bahasan Sistem Pencernaan. Metode dalam penelitian ini adalah true ekperimental dengan menggunakan desain rancangan control group pretest-posttest design. Populasi dalam penelitian ini adalah siswa kelas IV SD Negeri Tejamaya. Sampel sebanyak 2 kelas yang diambil secara total sampling, satu kelas sebagai kelas eksperimen yaitu kelas IV A sebanyak 35 orang dan dan satu kelas sebagai kelas kontrol yaitu IV B sebanyak 36 orang. Teknik pengumpulan data dilakukan dengan memberikan ujian tukis (pretest dan posttest) untuk memperoleh data kemampuan hasil belajar siswa. Hasil data penelitian sudah diuji prasyarat normalitas dan homogenitasnya dan kemudian teknik analisis data yang digunakan adalah uji perbedaan dua rata-rata (uji-t) dengan taraf signifikan $(\alpha)=5 \%$. Berdasarkan analisis data dan pengujian hipotesis menunjukkan bahwa adanya peningkatan yang signifikan hasil belajar siswa SD yang proses pembelajarannya menggunakan model Brain Bassed Learning $(B B L)$. Nilai n-gain untuk kelas eksperimen 0,82 dan untuk kelas kontrol 0,62.
\end{abstract}

Kata Kunci:

Learning Start With a Question, Hasil belajar, Sistem Indra

\begin{abstract}
The Brain Based Learning (BBL) Model in this reseach is applied for improvement of learning outcomes in primary school for subject of sensory Systems. Metodology of this reseach is true experimental by using control group pretestposttest design. The population of students class IV SD Negeri Tejamaya. The sample of 2 classes taken total sampling, that one class as experimental class is IV A the number of sample is 35 tudents and the class as control class is IV B the number of sample is 36 students. Data collection techniques are paper test (pretest and posttest) to obtain data on student learning outcomes. The research's data are done with consider their normality an homogenity, and then the data analysis technique is used mean difference test with t-test with a significant level $(\alpha)=5 \%$. Based on data analysis and hypothesis testing shows that there is a significant increase in learning outcomes of primary school student whose learning process uses the Brain Based Learning (BBL) model. The n-gain value for the experimental class is 0,82 and for the control class 0,62 .
\end{abstract}

Keywords:

Brain Based Learning, Learning Outcomes, Sensory System

\section{A. PENDAHULUAN}

Perkembangan ilmu pengetahuan, teknologi, dan seni berlangsung secara terusmenerus seirama dengan perkembangan zaman yang tidak pernah berhenti, dan selalu memunculkan hal-hal baru dalam kehidupan. Sehingga perkembangan didunia pendidikan juga menujukkan kemajuan yang bertahap.
Penerapan Kurikulum Tingkat Satuan Pendidikan (KTSP) dari pergantian kurikulum 2004 sebagai suatu pembaruan di bidang pendidikan. Implementasi KTSP akan berpengaruh pada guru sehingga guru akan terlibat langsung untuk membina, mengarahkan dan mengembangkan kemampuan peserta didik. Selain hal tersebut, 
kurikulum ini mengharuskan siswa aktif dalam pembelajaran (Student centre) sehingga diharapkan diharapkan siswa akan memperoleh pembelajaran bermakna.

Pembelajaran sains termasuk biologi merupakan bagian dari pendidikan yang memiliki peranan penting dalam peningkatan mutu pendidikan, khususnya dalam menghasilkan peserta didik yang berkualitas. Pengoptimalan penguasaan IPA khususnya mata pelajaran Biologi, seharusnya bukan untuk pemberian materi dan informasi saja tetapi harus menekankan pada pemberian pengalaman langsung untuk mengembangkan kompetisi agar peserta didik menjelajahi dan memahami alam sekitar secara ilmiah, sehingga dapat membantu peserta didik untuk memperoleh pemahaman yang lebih mendalam tentang dirinya sendiri dan alam sekitar. Sejalan dengan pendapat dari Setiawan (Saparina, riska et.al., 2015:59) "Keberhasilan dalam pembelajaran biologi dapat ditunjukan dari kualitas peserta didik, salah satunya dapat dilihat dari hasil belajar yang dicapai peserta didik". Pencapaian hasil belajar siswa dapat dipengaruhi oleh beberapa faktor, baik faktor internal maupun faktor eksternal. Faktor eksternal, khususnya faktor sekolah berpengaruh langsung terhadap pembelajaran siswa disekolah, salah satunya adalah faktor model pembelajaran, karena di dalam model pembelajaran sudah terdapat tahap-tahap pembelajaran dari awal sampai akhir pembelajaran. Sehingga diperlukan model pembelajaran yang dapat meningkatkan minat siswa untuk mencapai pemahaman tanpa rasa bosan dengan menciptakan suasana belajar yang nyaman.

Menurut Ward (Nofla, Meri Yesi 2015:1) menyatakan "Poin utama jika kita ingin membantu siswa belajar sains, pengajaran harus mempertimbangkan cara siswa belajar dan agar dapat melakukannya secara efektif, membutuhkan pemahaman akan peran otak dalam proses belajar". Otak ini terdiri dari belahan otak kanan, belahan otak kiri dan belahan otak tengah. Semua belahan ini memiliki peran penting yang terlibat dalam setiap aktivitas. Disaat otak kiri bekerja mengapal rumus, berpikir kiritis sedangkan otak kanan bekerja saat ada musik klasik, gambar-gambar menarik dan sebagainya, maka seorang guru harus mampu memberikan pengajaran yang meyeimbangkan kerja otak dengan cara belajar yang menarik, menyenangkan, efektif, dan aktif. Sehingga anak menjadi lebih senang dan ikut berpartisipasi dalam proses pembelajaran yang berlangsung. Alternatif model yang dapat digunakan untuk membantu pengembangan otak kanan dan kiri siswa terutama untuk jenjang sekolah dasar bisa dengan menggunakan model Brain Based Learning (BBL). Menurut pendapat Jensen, Eric (2011:6) menyatakan bahwa "Pendidikan berbasis otak dipahami paling baik dalam tiga kata: keterlibatan, strategi dan prinsip." Prinsip dari Brain Based Learning yaitu belajar melibatkan proses sadar dan tak sadar, hafalan, melibatkan seluruh fisiologi, pencarian makna, dan otak memahami fakta terbaik ketika tertanam didalam memori.

Jadi Brain Based Learning ini membantu guru membangkitkan kinerja otak peserta didik seperti menciptakan lingkungan belajar yang menantang dan menyenangkan sehingga peserta didik berperan aktif dan proses pembelajaran juga akan bermakna bagi peserta didik.

\section{Metode penelitian}

Metode yang digunakan penulis pada penelitian ini adalah true experimental. Menurut Sugiyono (2015:75) "True experimental (eksperimen yang betul-betul), karena dalam desain ini peneliti dapat mengontrol semua variabel luar yang mempengaruhi jalannya eksperimen".

Subjek dalam penelitian ini adalah siswa kelas IV SD Negeri Tejamaya. Kelas IV A sebagai kelas eksperimen sebanyak 35 orang dan IV B sebagai kelas kontrol sebanyak 36 orang. Siswa diberikan tes sebelum dan sesuadah pembelajaran pada topik sistem indra. Selain tes, peneliti juga melakukan wawancara terhadap siswa. Selain itu peneliti juga mengamati proses pembelajaran biologi yang berlangsung 
dikelas. Pengamatan ini bertujuan untuk melihat bagaimana guru menerapkan model pada konsep yang diajarkan.

\section{Disain Penelitian}

Disain penelitian ini adalah PretestPosttest Control group Design. Adapun desain penelitian adalah sebagai berikut:

Rancangan
$\mathrm{R}$
$\mathrm{O}_{1} \quad \mathrm{X}$
$\mathrm{O}_{2}$
$\mathrm{R}$
$\mathrm{O}_{3}$
$\mathrm{O}_{4}$

Keterangan :

Tabel 1

Statistik Deskriptif nilaip pretest, postes dan n-gain kelas eksperimen dan kelas kontrol

\begin{tabular}{|c|l|c|c|c|c|c|c|}
\hline \multirow{2}{*}{ Nilai } & Kelas & \multirow{2}{*}{$\mathrm{N}$} & \multicolumn{6}{|c|}{ Tes Hasil Belajar } \\
\cline { 3 - 8 } & & & $\begin{array}{c}\text { Skor } \\
\text { Ideal }\end{array}$ & $\begin{array}{c}\text { Skor } \\
\text { Min }\end{array}$ & $\begin{array}{c}\text { Skor } \\
\text { Max }\end{array}$ & $\mathrm{X}$ & SD \\
\hline \multirow{2}{*}{ Pretest } & Eksperimen & 35 & 41 & 12 & 29 & 20,94 & 4,57 \\
\cline { 2 - 8 } & Kontrol & 36 & 41 & 12 & 29 & 19,97 & 5.16 \\
\hline \multirow{2}{*}{ Postest } & Eksperimen & 35 & 41 & 20 & 36 & 32,06 & 3,60 \\
\cline { 2 - 8 } & Kontrol & 36 & 41 & 18 & 33 & 18.57 & 4,54 \\
\hline \multirow{2}{*}{ N-gain } & Eksperimen & 35 & - & 0,31 & 0,82 & 0,56 & 0,14 \\
\cline { 2 - 8 } & Kontrol & 36 & - & 0,12 & 0.62 & 0.38 & 0,14 \\
\hline
\end{tabular}

Berdasarkan tabel 1 diketahui rata-rata nilai kedua kelompok setelah pembelajaran, kelompok siswa yang mendapatkan pembelajaran dengan menggunakan model pembelajaran Brain Based Learning (BBL)
$\mathrm{R} \quad$ : kelompok yang dipilih secara random

$\mathrm{X}$ : perlakuan (treatment)

$\mathrm{O}_{1}$ : Pre-test pada kelas eksperimen

$\mathrm{O}_{2}$ : Post-test pada kelas eksperimen

$\mathrm{O}_{3}$ : Pre-test pada kelas kontrol

$\mathrm{O}_{4}$ : Post-test pada kelas kontrol

B. Hasil Penelitian dan Pembahasan

1. Hasil Belajar Kelas Eksperimen dan kelas kontrol

Hasil pengolahan data nilai pretest postest dan $N$-gain hasil belajar siswa kelas eksperimen dan kelas kontrol dapat dilihat pada tabel berikut :

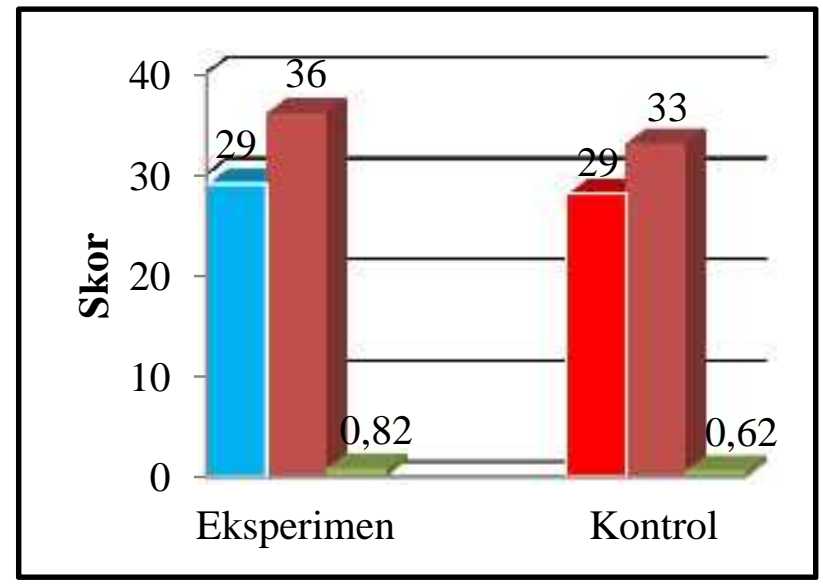

Gambar 1 


\section{Skor Hasil Belajar Siswa pada Kelas Eksperimen dan Kelas Kontrol}

Dengan demikian dapat disimpulkan bahwa rata-rata skor hasil belajar siswa kelas eksperimen setelah pembelajaran Brain Based Learning (BBL) lebih tinggi dari kelas kontrol. Untuk mengetahui signifikasi perbedaan skor kedua kelas maka dilakukan uji t dua rata-rata.

Selain data diatas berikut disajikan beberapa rata-rata perbedaan skor untuk masing-masing ranah kognitif siswa. Disajikan dalam grafik berikut :

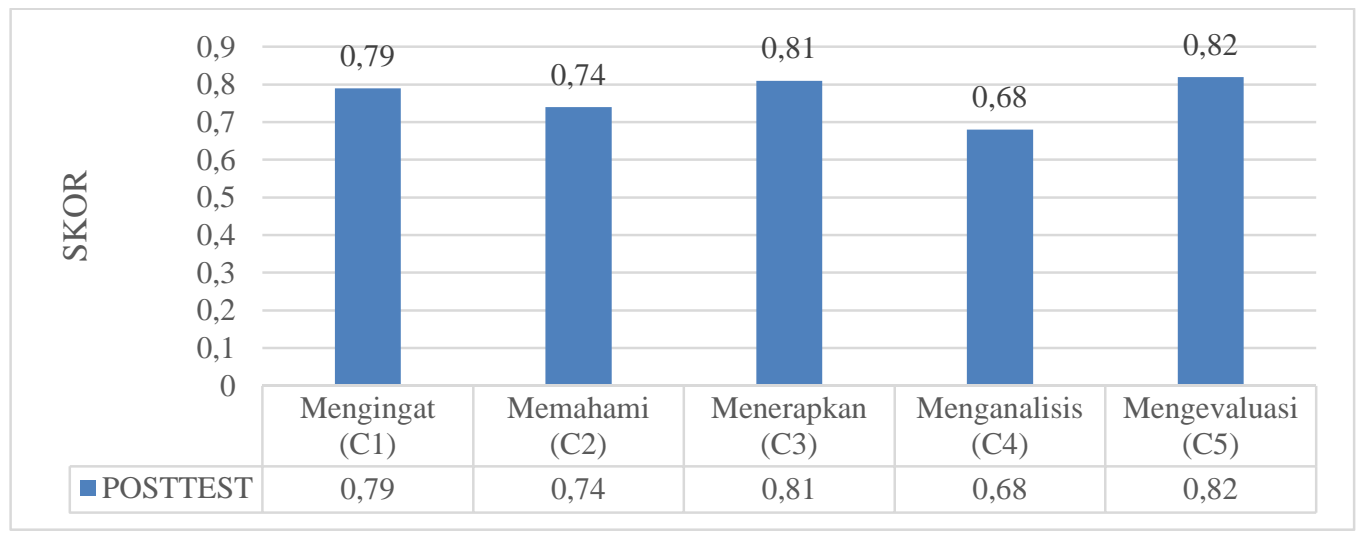

Gambar 2.

Diagram Rata-rata Skor Hasil Belajar dalam Setiap Indikator di Kelas Eksperimen

Gambar 2 menunjukkan bahwa rata-rata skor posttest tertinggi hasil belajar terdapat pada dimensi mengevaluasi yaitu 0,82 dan skor posttest terendah terdapat pada indikator menganalisis yaitu 0,68. Perbedaan skor tersebut disebabkan karena setiap soal memiliki kriteria yang berbeda. Pada soal aspek kognitif mengevaluasi, peserta didik telah mampu menjawab pertanyaan, karena dimensi ini menuntut peserta didik mengambil keputusan berdasarkan penilaian atau pertimbangan suatu konsep dalam sebuah soal. Namun, berbeda halnya dengan soal dimensi kognitif menganalisis, peserta didik harus menguraikan konsep ke dalam bagianbagian yang lebih terstruktur, mengidentifikasi hubungan antar konsep sehingga hal tersebut memunculkan kesulitan tersendiri bagi sebagian peserta didik.

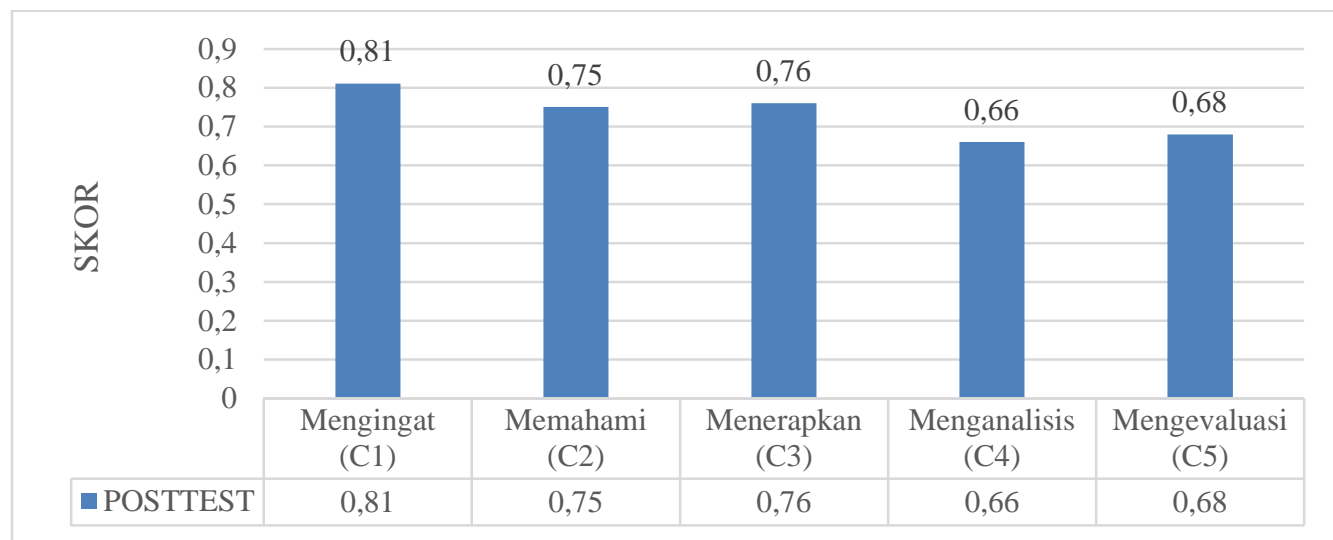

Gambar 3.

Diagram Rata-rata Skor Hasil Belajar dalam Setiap Indikator di KelasKontrol 
Gambar 3 memperlihatkan bahwa ratarata skor posttest tertinggi hasil belajar terdapat pada dimensi mengingat yaitu 0,81 dan skor posttest terendah terdapat pada indikator menganalisis yaitu 0,66 . Perbedaan skor tersebut disebabkan karena setiap soal memiliki kriteria yang berbeda. Pada soal dimensi proses kognitif mengingat, peserta didik hanya dituntut satu kali berpikir yakni dengan mengingat konsep mereka telah mampu menjawab pertanyaan. Namun, berbeda halnya dengan soal dimensi kognitif menganalisis, peserta didik harus menelaah suatu permasalahan dalam sebuah soal secara lebih detail sehingga mereka dapat menjawab soal dengan benar. Hal tersebut memunculkan kesulitan tersendiri bagi sebagian peserta didik.

Berdasarkan grafik diatas perbedaan rata-rata perolehan skor perindikator pada ranah kognitif dikelas eksperimen dan kontrol, dapat dibandingkan hasilnya cukup signifikan terutama pada ranah kognitif pada C3. C4 dan C5 pada kelas eksperimen jauh lebih tinggi dibandingkan dengan kelas kontrol.

\section{B. HASIL DAN PEMBAHASAN}

\section{Hasil Belajar Peserta Didik yang Proses Pembelajarannya Menggunakan Model Brain Based Learning dengan Pembelajaran Langsung}

Berdasarkan hasil analisis uji $t$ independen skor rata-rata hasil belajar kelas eksperimen dan kontrol di peroleh t-hitung $=$ 6 dan t-tabel $=2,00$. Dengan analisis thitung > t-tabel sehingga kesimpulan analisisnya tolak Ho yang artinya ada pengaruh penggunaan model brain based learning terhadap hasil belajar peserta didik pada materi sistem indra di kelas IV SD Negeri Tejamaya. Hal tersebut pada kelas eksperimen menggunakan model brain based learning, model brain based learning merupakan salah satu model pembelajaran yang diselaraskan dengan cara otak, cara tersebut kemudian didesain secara ilmiah untuk belajar. Karena ketika belahan otak kiri dan kanan digunakan maka kekuatan dan fungsi-fungsi otak kanan dan kiri tersebut bekerja secara maksimal. Berdasarkan fungsinya tentu berbeda antara otak kanan dan kiri, otak kiri mengontrol gerak tubuh bagian kiri, menganalisis, bebicara, menulis, keterampilan dalam angka secara ilmiah. Sedangkan otak kanan mengontrol tubuh bagian kanan, kreativitas dan emosi. Dampak positif yang dapat dirasakan adalah ketika otak kanan dan kiri digunakan ialah kecerdasan sesorang akan meningkat, fungsi kedua belahan otak tersebut tidak bekerja sendiri tetapi saling mempengaruhi satu sama lain. Hal tersebut sejalan dengan Silvana, Hana, et,al., (2016:305):

"Pembelajaran berbasis otak merupakan sebuah cara berpikir tentang proses pembelajaran. Pendekatan ini adalah pembelajaran yang diselaraskan dengan cara otak yang didesain secara alamiah untuk belajar. Ketika belahan otak kanan dan otak kiri digunakan, maka kekuatan dan fungsi-fungsi otak manusia maksimal. Bahkan bekerjanya pun maksimal. Dampak positif yang bisa dirasakan ialah kecerdasan seseorang atau seorang anak akan semakin meningkat. Fungsi otak tersebut tidak hanya bekerja sendirisendiri tetapi saling mempengaruhi satu sama lain"

Berdasarkan diagram perbedaan skor pretest, posttest, $\mathrm{N}$-gain kelas eksperimen dan kelas kontrol bahwa rata-rata posttest hasil belajar peserta didik di kelas eskperimen yang proses pembelajarannya menggunakan model brain based learning lebih tinggi dibandingkan dengan rata-rata posttest hasil belajar peserta didik di kelas kontrol. Sehingga $N$-gain yang diperoleh menunjukan rata-rata $N$-gain di kelas eksperimen yang proses pembelajarannya menggunakan model brain based learning lebih tinggi yaitu 0,82 dibandingkan $\mathrm{N}$-gain hasil belajar peserta didik di kelas kontrol yaitu 0,62.

Hal ini menunjukan bahwa proses pembelajaran yang menggunakan model brain based learning dapat merangsang keaktifan peserta didik dan meningkatkan 
hasil belajar peserta didik sehingga memberikan pengaruh terhadap hasil belajar peserta didik dibandingkan dengan pembelajaran langsung di kelas kontrol. KKM untuk mata pelajaran biologi kelas IV SD Negeri Tejamaya adalah 28,7. Dari data tersebut diketahui bahwa kelas eksperimen telah mencapai KKM yaitu dengan rata-rata 32,06 sedangkan kelas kontrol belum mencapai KKM yaitu 28. Dengan begitu di dapat bahwa kelas eksperimen sudah mencapai kriteria ketuntasan minimal (KKM), sedangkan kelas kontrol belum mencapai kriteria ketuntasan minimal (KKM). Sehingga dapat disimpulkan bahwa proses pembelajaran model brain based learning dapat meningkatkan hasil belajar peserta didik di kelas IV SD Negeri Tejamaya.

Berdasarkan hasil penelitian, proses pembelajaran brain based learning lebih baik dibandingkan dengan yang menggunakan model pembelajaran langsung. Dengan model brain based learning pembelajaran peserta didik di kelas menjadi kondusif, karena model pembelajaran ini melatih peserta didik untuk mengeluarkan semua kemampuan berpikirnya untuk berpikir kreatif dan keaktifan disaat kegiatan belajar berlangsung ,peserta didik juga dilatih untuk bekerja sama dengan kelompoknya sehingga dapat menumbuhkan rasa saling menghargai antara teman sebayanya ketika melaksanakan diskusi dan presentasi. Berdasarkan pembahasan tersebut, dapat disimpulkan bahwa terdapat pengaruh model brain based learning terhadap hasil belajar peserta didik pada materi sistem Indra di kelas IV SD Negeri Tejamaya.

Pada model brain based learning memberikan pengaruh terhadap keaktifan peserta didik dalam berperan aktif dalam pembelajaran. Dalam model brain based learning guru terlebih dahulu menyampaikan point materi melelui bagai sehingga peserta didik dapat menangkap point-point materi untuk dipahami, selain itu juga peserta didik dapat dengan mudah menangkap hubunganhubungan antar materi. Kemudian setelah itu peserta didik diberikan kesempatan untuk menyusun kembali informasi yang didapat yang kemudian dituangkan kedalam lembar kerja peserta didik, setelah itu lembar peserta didik yang telah dikerjakan secara berkelompok dipresentasikan dan didiskusikan didepan kelas, sehingga guru dapat menyelidiki apa yang telah diketahui oleh peserta didik bagian konsep mana yang salah, dengan hal itu juga guru dapat mengetahui peserta didik yang aktif. Selain itu suasanya belajarpun menjadi lebih hidup dan menyenangkan serta dapat merangsang minat belajar peserta didik untuk memunculkan ide terpendam yang dimiliki dan membuat asosiasi diantara ide tersebut. Hasil uji t kelas eksperimen yaitu t-hitung $=-19,90$ terletak di daerah penolakan Ho. Kesimpulan Tolak Ho yang artinya terdapat perbedaan yang signifikan hasil belajar peserta didik sebelum pembelajaran menggunakan model brain based learning dengan sesudah pembelajaran menggunakan model brain based learning.

Hal tersebut sesuai dengan kelebihankelebihan yang dikemukakan oleh J Robo, Rusnia (2013:1) yang telah dibahas di kajian teoritis, yaitu menciptakan lingkungan belajar yang menantang kemampuan berpikir siswa, menciptakan lingkungan pembelajaran yang menyenangkan, menciptakan situasi pembelajaran yang aktif dan bermakna bagi siswa (active learning). Adapun kelebihankelebihan dari model brain based learning menurut Ozden dan Mehmet (Agustina, Novia Wahyu dan Hanifah 2017:358-364) mengemukakan kelebihan model brain based learning yaitu pembelajaran dikaitkan dengan kehidupan nyata, sehingga memudahkan siswa dalam mencari pola dan makna, siswa berpartisipasi langsung dalam proses belajar, lingkungan belajar yang membuat siswa nyaman membantu dalam proses pembelajaran bermakna, membangun pola dan hubungan di otak sebagai pengalaman yang kompleks dan membuat belajar lebih permanen. Sedangkan penggunaan model pembelajaran langsung di kelas kontrol melalui model pembelajaran langsung cenderung kurang memotivasi peserta didik tidak mencari pengalaman berlajar dalam mencari solusi untuk memecahkan masalah 
secara nyata, sehingga hasil belajar yang diperoleh kurang maksimal. Peserta didik hanya mengetahui solusi berupa teori, tidak memberikan pengalaman terhadap peserta didik.

Guru mengendalikan isi materi dan urutan informasi yang diterima oleh peserta didik sehingga dapat mempertahankan fokus mengenai apa yang harus dicapai oleh peserta didik, selain itu model pembelajaran langsung juga dapat menjadi cara untuk menyampaikan informasi yang banyak dalam waktu yang relatif singkat yang dapat diakses secara setara oleh seluruh peserta didik. Akan tetapi proses pembelajaran dikelas cenderung menjadi lebih pasif, cepat bosan dan jenuh dengan kegiatan belajarnya. Oleh karena itu tidak sedikit peserta didik yang mencari kesibukan lain seperti mengobrol dengan teman sebangkunya tanpa memperhatikan lagi apa yang disampaikan oleh guru, sehingga hasil belajar yang diperoleh masih kurang memuaskan.

\section{SIMPULAN}

Berdasarkan hasil analisis data dan pengujian hipotesis, maka diperoleh simpulan bahwa terdapat pengaruh model pembelajaran Bain Based Learning (BBL) terhadap hasil belajar peserta didik pada Materi Sistem Indra di kelas IV SD Negeri Tejamaya dengan skor $\mathrm{N}$-Gain kelas eksperimen 0.82 dan kelas kontrol 0,62.

\section{DAFTAR PUSTAKA}

Agustina, Novia Wahyu dan Hanifah (2017). Pembelajaran Berbasis Otak (Brain Based Learning), Gaya Kognitif Kemampuan Berpikir Kreatif Dan Hasil Belajar Mahasiswa. P-ISSN: 2303-
288X E-ISSN: 2541-7207, Vol. 6, No. $1, \mathrm{hlm} 358-364$.

J Robo, Rusnia. (2013). Brain Based Learning. Mahasiswa UMM https://kasatamahakarya./2013/07/25/br ain-based-learning : diakses (20 Agustus 2017)

Jensen, eric. (2008). Brain Based Learning. Yogyakarta: PT Indeks

Jensen, eric. (2011). Pembelajaran BerbasisOtak Paradigma Pengajaran Baru. Jakarta: PT Indeks

Meri, Yesi Nofla. (2015). Peningkatan Keterampilan Proses Sains pada Pembelajaran IPA Terpadu Tipe Webbed dan Connected Berbasis Brain Based Learning. Proseding Seminar Nasional Fisika (E-Journal)SNF2015. Vol IV

Saparina, riska. Dkk. (2015). "Pengaruh Model Brain Based Learning (BBL) Terhadap Belajar Biologi Siswa Kelas $X$ SMA Negeri Colomadu Tahun Pelajaran 2012/2013. Jurnal BioPedagigi.4(1).59-65.

Silvana, Hana. dan Wibisono, Adhitya (2016). Penerapan Model Brain Based Learning dalam Pembelajaran di Sman 10 Bandung. Ethos (Jurnal Penelitian dan Pengabdian Masyarakat), Vol. 4, No. 2, hlm.303-310.

Sugiyono. (2015). Metode Penelitian Kuantitatif Kualitatif dan $R \& D$. Bandung: ALFABETA cv. 